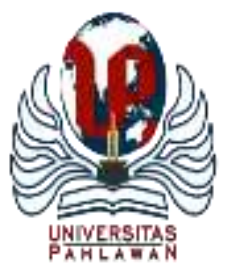

Edukatif : Jurnal Ilmu Pendidikan Volume 3 Nomor 6 Tahun 2021 Halm 5017 - 5023

EDUKATIF: JURNAL ILMU PENDIDIKAN

Research \& Learning in Education

https://edukatif.org/index.php/edukatif/index

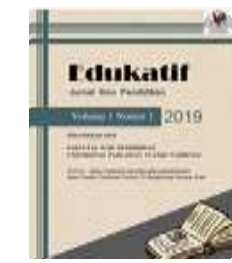

\title{
Implementasi Pembelajaran : Peluang dan Tantangan Pembelajaran Tatap Muka bagi Siswa Sekolah Dasar di Muara Komam
}

\author{
Adiyono \\ Sekolah Tinggi Ilmu Tarbiyah (STIT) Ibnu Rusyd, Indonesia \\ E-mail : Adiyono8787@gmail.com
}

\begin{abstract}
Abstrak
Semenjak pandemi pembelajaran daring menjadi pilihan yang tepat untuk menekan tersebarnya virus corona, namun dalam prosesnya, terdapat tantangan dan peluang pembelajaran tatap muka yang dialami oleh seluruh siswa di Indonesia secara khusus bagi siswa sekolah dasar di Muara Komam. Tujuan dari penelitian ini adalah untuk mendeskripsikan peluang serta tantangan pembelajaran tatap muka bagi siswa sekolah dasar di Kampung Muara Komam selaku daerah 3T Terdepan, Tertinggal, Terluar, metode yang digunakan adalah kualitatif dengan pendekatan deskriptif. Hasil penelitian menunjukkan adanya pengaruh metode flipped classroom terhadap hasil belajar mahasiswa pada pembelajaran tatap muka terbatas sehingga pemilihan metode yang sesuai pada pembelajaran tatap muka terbatas dapat mengoptimalkan hasil belajar siswa. Sebagian sekolah mulai melaksanakan Pembelajaran Tatap Muka (PTM) terbatas dengan protokol kesehatan. Meski terdapat pro dan kontra, menurut pemerintah, pembukaan sekolah merupakan pilihan untuk menaikan capaian hasil belajar. Warga sekolah diharapkan segera beradaptasi dengan cara belajar baru di era pandemic covid-19.
\end{abstract}

Kata Kunci : Implementasi pembelajaran, tantangan, peluang.

\section{Abstract}

Since the online learning pandemic has become the right choice to suppress the spread of the corona virus, but in the process, there are challenges and face-to-face learning opportunities experienced by all students in Indonesia, especially for elementary school students in Muara Komam. The purpose of this study is to describe the opportunities and challenges of face-to-face learning for elementary school students in Muara Komam Village as the Frontier, Disadvantaged, Outermost $3 T$ area) the method used is qualitative with a descriptive approach. The results showed that there was an effect of the flipped classroom method on student learning outcomes in limited face-to-face learning so that the selection of appropriate methods in limited faceto-face learning could optimize student learning outcomes. Some schools have started implementing limited Face-to-face Learning (PTM) with health protocols. Although there are pros and cons, according to the government, opening schools is an option to increase learning outcomes. School residents are expected to immediately adapt to new ways of learning in the era of the COVID-19 pandemic.

Keywords: Implementation of learning, challenges, opportunities.

Copyright (c) 2021 Adiyono

$\triangle$ Corresponding author

Email : Adiyono8787@gmail.com

DOI : https://doi.org/10.31004/edukatif.v3i6.1535 
5018 Implementasi Pembelajaran : Peluang dan Tantangan Pembelajaran Tatap Muka bagi Siswa Sekolah Dasar di Muara Komam - Adiyono

DOI: https://doi.org/10.31004/edukatif.v3i6.1535

\section{PENDAHULUAN}

Sejak pandemic Covid 19 Indonesia, Pemerintah mengumumkan secara resmi kasus Covid-19 pertama di Indonesia pada tanggal 2 maret 2020. Dua warga Indonesia yang positif mengatakan bahwa melakukan kontak langsung dengan warga Negara Jepang yang sedang berkunjung ke Indonesia. Di awali pada Tanggal 11 maret 2020, untuk pertama kalinya ada kasus meninggal diakibatkan karena virus corona tersebut. Korban yang meninggal adalah pria berusia 59 tahun warga asal solo jawa tengah (Sukur, 2020). Sejak saat itulah seluruh kebijakan pun mulai dibuat untuk meminimalisir terjadinya penyebaran Virus Covid-19 mulai dari Social Distacing, Physical Distancing serta pembelajaran daring. Pemerintah melalui Kementrian Pendidikan dan Kebudayaan, telah mengeluarkan Surat Edaran No. 4 tentang Pelaksanaan Kebijakan Pendidikan dalam Masa Darurat Penyebaran Corona Virus Disease (Covid-19) terhitung mulai 24 Maret 2020. Adanya surat tersebut, menyebabkan semua instansi mengambil langkah cepat sebagai respon antisipasi penyebaran Covid19 dan pelaksanaan proses pembelajaran. Berbagai upaya dilakukan sekolah untuk untuk meningkatkan kinerja sekolah dalam mencapai tujuan pendidikan yang ingin dicapai oleh sekolah di dalam kondisi pandemi (Irlana et al., 2021).

Berbagai pemanfaatan media diimplementasikan untuk menunjang pendidikan dan sebagai perantara pembelajaran. Pembelajaran yang semula bersifat tradisional dirubah menjadi lebih modern (Faiz, Hakam, et al., 2021). Perantara yang awalnya dilaksanakan di kelas diganti dengan media perantara seperti computer, laptop, handphone dan internet. Terdapat dua jenis dalam pembelajaran online yaitu di kenal dengan asynchronous and synchronous online learning, asynchronous adalah proses siswa belajar mandiri dengan bahan belajar yang terlah di sediakan sedangan synchronous merupakan proses belajar secara langsung menggunakan media web meeting (Nizam, \& Aris, 2009).

Secara umum, pembelajaran online yang dipaksakan menyisakan berbagai macam persoalan, antara lain akses internet yang terbatas, kesiapan guru dan orang tua, dan adaptasi siswa (Peimani, N., \& Kamalipour, 2021). Menurut Suni Astini (2020) kompetensi guru memanfaatkan teknologi dan informasi dalam pembelajaran masih kurang sehingga pemerintah mengeluarkan kebijakan pembelajaran tatap muka (PTM) terbatas yang tentu saja tidak sama dengan pembelajaran tatap muka seperti biasanya dikarenakan waktu pertemuan antara guru dan mahasiswa sangat terbatas. Untuk mengoptimalkan permbelajaran tatap muka terbatas, pembelajaran harus dirancang dengan cernat dan menerapkan metode pembelajaran yang sesuai agar pembelajaran tatap muka terbatas dapat terlaksana secara optimal dan mencapai tujuan pembelajaran, karena penggunaan metode pembelajaran yang tepat dapat meningkatkan hasil belajar (Mega Persada, N., Eko Pramono, 2017).

Selama situasi Covid-19 yang belum pernah terjadi sebelumnya, cakrawala pendidikan dan penilaian berkembang pesat dengan transformasi menuju pembelajaran dengan penggunaan teknologi. Hal ini secara signifikan telah mengganggu proses pembelajaran. Namun, perkembangan teknologi telah memungkinkan untuk mengadaptasi pedagogik pengajaran yang efektif seperti model kelas e-flipped yang dapat memfasilitasi penyampaian pengetahuan (Jamilah, 2020). Metode flipped classroom dapat diterapkan pada pembelajaran tatap muka terbatas karena mengombinasikan pembelajaran di luar kelas dan di dalam kelas (Kurniati, E., Nur Alfaeni, D. K., \& Andriani, 2020).

Pembelajaran Tatap Muka (PTM) terbatas dan Pembelajaran Jarak Jauh (PJJ) dapat dilaksanakan pada 99\% satuan pendidikan yang berada pada situasi Covid -19 level 3 dan 2 berdasarkan SKB 4 Menteri,sementara satuan pendidikan yang berada pada daerah level 4 sepenuhnya PJJ. Penyelenggaraan pembelajaran tatap muka terbatas pada level 3,2 dan 1 masih bervariasi di tingkat provinsi (Kemendikbudristek, 2021).

Persentase PTM terbatas dan PJJ dihitung dari pelaporan 275.224 satuan pendidikan (51\%dari total satuan pendidikan). Yaitu 42\% satuan pendidikan yang berada pada level 3,2 dan 1 selama peberlakuan 
PPKM menyelenggarakan pembelajaran tatap muka terbatas. Pembelajaran Jarak Jauh (PJJ) tingkat PAUD $61 \%$, tingkat SD/MI 58\%, tingkat SMP/MTS 54\%, dan tingkat SMA 50\%, serta Pembelajaran Tatap Muka (PTM) Terbatas tingkat SMK/MAK 52\%, tingkat SLB 60\%, tingkat SKB/PKBM 66\%, tingkat Kursus 31\% (Kemendikbud, 2021).

Terlepas advokasi bersama antara Kemdikbudristek, Kemendagri, Kemenag, Kemenkes, dan Satgas Covid-19 Nasional, kendala terbesar pelaksanaan pembelajaran tatap muka terbatas adalah belum diberikannya izizn oleh pemda/satgas Covid-19 daerah. Survei dari pelaporan 55.945 satuan pendidikan yang belum melaksanakan PTM terbatas pada aplikasi survei PTM pada jenjang PAUD Dikdasmen di bawah Kemdikbudristek tanggal 20 Sempember 2021.

\section{METODE PENELITIAN}

Pendekatan penelitian ini menggunakan kualitatif yang bertujuan untuk mengamati objek secara alamiah (Faiz \& Soleh, 2021). Metode penelitian yang digunakan dalam penelitian ini adalah metode deskriptif. Metode deskriptif adalah suatu metode dalam meneliti status sekelompok manusia, suatu objek, kondisi, sistem pemikiran ataupun peristiwa pada masa sekarang (Faiz, 2019). Dengan dasar tersebut maka tujuan penelitian ini untuk memberikan gambaran peluang serta tantangan pembelajaran daring yang ada di Kampung Muara Komam selaku Daerah 3T (Tertinggal, Terluar dan Terdepan). Subjek dalam penelitian ini adalah Guru Sekolah Dasar Negeri 016 Muara Komam sebanyak 5 Orang dan Guru Sekolah Dasar Negeri 018 Muara Komam, Siswa sebanyak 12 orang. Sumber data dalam penelitian ini terbagi menjadi dua yaitu data primer dan data sekunder. Data primer adalah data yang diperoleh peneliti secara langsung (dari tangan pertama), sementara data sekunder adalah data yang diperoleh peneliti dari sumber yang sudah ada.Cara mengumpulkan data penelitian adalah dengan menggunakan Purpose Sampling yaitu setiap subjek memiliki kesempatan yang sama untuk menjadi sampel dalam penelitian. Teknik mengumpulkan data adalah dengan Wawancara semi terstruktur yang kemudian hasil wawancara tersebut dianalisis mulai dari reduksi data, display data dan penarikan kesimpulan. Data yang telah terkumpul kemudian dianalisis dengan menggunakan Reduksi data, Penyajian Data Data, dan penarikan kesimpulan.

\section{HASIL DAN PEMBAHASAN}

Sejak adanya pandemi covid-19 pembelajaran dilakukan secara daring/jarak jauh atau pembelajaran dilakukan dari rumah. Selama pembelajaran jarak jauh tersebut guru harus berupaya melakukan banyak variasi pembelajaran untuk meningkatkan motivasi peserta didik (Hanina et al., 2021). Namun saat pandemi mulai melandai pemerintah memberikan kelonggaran bagi dunia pendidikan untuk bisa melakukan pembelajaran tatap muka terbatas. Adapun penelitian ini bertujuan untuk menjabarkan hasil penelitian terkait tantangan pembelajaran tatap muka serta peluang pembelajaran tatap muka pada Sekolah Dasar Negeri Muara Adang.

\section{Peluang Pembelajaran Tatap Muka Bagi Siswa Sekolah Dasar Di Muara Komam}

Jika membicarakan peluang pembelajaran tatap muka langsung, tentu diperlukan dukungan yang kuat dari berbagai stakeholder pendidikan dan kesadaran dari diri siswa tersebut (Pradina et al., 2021). Adapun aspek-aspek dan peluang yang perlu diperhatikan dalam persiapan PTM diantaranya; Pertama, meningkatkan capaian hasil belajar siswa. PTM terbatas harus disiapkan secara matang untuk mengatasi kelemahankelemahan Pembelajaran Jarak Jauh (PJJ). Dalam waktu yang terbatas di kelas, 2 sampai 3 jam, dan hanya 2 sampai 3 hari di sekolah, guru harus memanfaatkan waktu sebaik mungkin. Selain belajar di sekolah, siswa tetap melaksanakan pembelajaran daring. Maka disebut pembelajaran bauran. Guru harus merancang dengan 
baik, aktivitas-aktivitas pembelajaran di kelas dan di rumah. Luring dan daring. Mengacu kepada pedoman PTM Kemdikbudristek, disesuaikan dengan kondisi sekolah.

Kedua, mengurangi putus sekolah. PTM diharapkan menarik minat belajar siswa yang terkendala internet, sinyal, listrik, motivasi, laptop, atau gawai. Sementara yang mengalami kendala biaya, semoga pemerintah daerah segera menyelesaikannya. Dinas pendidikan mengumpulkan kepala sekolah negeri dan swasta untuk meminimalisir putus sekolah. Disiapkan aneka skema penyelesaian putus sekolah, sesuai dengan faktor penyebab masing-masing siswa.

Ketiga, mengurangi kekerasan terhadap anak. Interaksi intensif anak dengan orang tua di rumah membuka peluang kekerasan terhadap anak. Kelemahan pengetahuan tentang cara mendidik anak mengakibatkan kekerasan dalam rumah. Kehadiran anak di sekolah diharapkan meringankan stress orang tua dan anak. Kelamaan di rumah dan pergaulan bebas menyebabkan pernikahan dini dan kehamilan pada anak. Sekolah membangun komunikasi dengan orang tua untuk bersama-sama menjalankan peran mendampingi belajar anak dan mendidik mereka dengan baik.

Peluang dari proses pembelajaran online adalah membiasakan siswa untuk berlatih belajar mandiri dengan bahan belajar yang telah disiapkan. Selain melatih siswa untuk mandiri belajar, kebiasaan tersebut mendorong siswa untuk memiliki rasa ingin belajar tanpa perlu instruksi dan perintah dari guru (Andrianto Pangondian, R., Insap Santosa, P., \& Nugroho, 2019). Hal demikian sejalan dengan Aliran progresivisme mendukung adanya pelaksanaan pendidikan yang berpusat pada peserta didik (student centered) dan bertujuan mengembangkan berbagai aspek kemampuan individu dalam menghadapi tantangan zaman yang semakin kompleks (Faiz \& Kurniawaty, 2020). Sedangkan melalui pembelajaran online, guru menjadi lebih berinovasi dalam memberikan pembelajaran yang menyenangkan dan tidak membosankan bagi siswa. Selain itu, kemampuan guru dalam menyusun pembelajaran mengalami peningkatan dan penyesuaian dengan pembelajaran online yang berbasis keterampilan literasi digital (digital literacy) (Kuntari Erimurti, 2016).

\section{Tantangan Pembelajaran Tatap Muka Bagi Siswa Sekolah Dasar Di Muara Komam}

Banyak kendala dan tantangan yang dihadapi oleh guru, orang tua, dan anak selama pembelajaran jarak jauh (PJJ) diantaranya: Pertama, keterbatasan internet. Pandemi memberikan momentum bagi pemerintah untuk pemerataan listrik, internet, dan fasilitas digitalisasi sekolah. Siswa yang ada di pulau-pulau terpencil bisa belajar jika ada fasilitas tersebut. Program laptop diharapkan tepat sasaran.

Kedua, kemampuan membeli kuota. Evaluasi program bantuan kuota bagi guru dan siswa harus terus dievaluasi sehingga tepat sasaran. Evaluasi juga diarahkan pada ketepatan penggunaan kuota untuk pembelajaran, bukan untuk nonpembelajaran. Program ini terutama harus menjangkau siswa miskin dan guru honorer yang gajinya di bawah Upah Minimum Provinsi (UMP) atau Upah Minimum Kota/ Kabupaten (UMK). Peran nonpemerintah akan membantu menyelesaikan masalah kuota internet. Kemampuan finansial juga kadang mempengaruhi penyelesaian tugas-tugas sekolah yang membutuhkan siswa membeli alat atau bahan tertentu. Kemiskinan jelas berpengaruh terhadap proses dan capaian belajar.

Ketiga, kepemilikian komputer atau laptop. PJJ yang ideal dilakukan menggunakan komputer atau laptop, bukan dengan telepon genggam. Pengerjaan tugas-tugas juga akan lebih mudah atau cocok menggunakan laptop. Ketiadaan laptop pasti memengaruhi proses belajar mengajar PJJ. Laptop menjadi kebutuhan utama belajar di era digital saat ini. Misal, beberapa tugas dan ujian disampaikan guru dalam aplikasi maya yang membutuhkan laptop sebagai medianya.

Keempat, literas digitial guru dan siswa. Dalam PJJ beberapa keterampilan digital harus dikuasai guru dan siswa, seperti mengetik, menggunakan mouse, menggunakan email, google class room, mencari informasi atau data di internet, membuat PPT, dan membuat video. Di masa pandemi, literasi digital sebagian guru dan siswa meningkat, sementara sebagian lainnya semakin tertinggal karena kelemahan bahkan ketiadaan listrik 
dan internet, serta laptop. Sebagian dapat tetap belajar dengan baik di era pandemi karena memiliki fasilitas digital dan guru-guru kompeten, sebagian lainnya mengalami penurunan capaian pembelajaran.

Kelima, disiplin protokol kesehatan. PTM terbatas harus dilaksanakan dengan protokol kesehatan. Setiap warga sekolah harus disiplin melaksanakan protokol ini agar tidak terjadi penularan virus di sekolah. Setiap warga sekolah harus dipastikan kesehatannya sebelum masuk ke sekolah, seperti pengukuran suhu tubuh. PTK divaksin 2 dosis,satuan pendidikanwajib menyediakan pembelajaran tatap muka terbatas dengan protokol kesehatan dan juga pembelajran jarak jauh. Ada beberapa hal yang penting diperhatikan diantaranya: wajib memenuhi daftar periksa, PTM tarbatas dikombinasikan dengan pembelajaran jarak jauh, orang tua/wali dapat memutuskan bagi anaknya untuk tetap PJJ, wajib melakukan pengawasan terhadap pelaksanakan pembelajaran. Jika terdapat kasus Covid-19 wajib melakukan penanganan kasus dan dapat memberhentikan sementara PTM. Serta berdasarkan kebijakan PPKM yang berada dalam ppkm level 4 harus melakukan PJJ. Kesiapan sarana sanitasi dan kebersihan serta ketersediaan fasilitas kesehatan pada mayoritas satuan pendidikan sudah baik, seperti; area wajib masker, akses ke fasilitas kesehatan, Thermogun (pengukur suhu tubuh), toilet dan kamar mandi bersih, sarana CTPS dengan air mengalir/ hand sanitizer dan disinfektan. Kecuali pada komponen pemetaan warga satuan pendidikan yang tidak boleh ke sekolah, seperti; riwayat kontak erat, riwayat perjalanan dari Zona resiko Covid tinggi, dan tidak memiliki akses transportasi yang aman.

Keenam, percepatan vaksinasi guru, staf, dan siswa. Menurut Kementerian Kesehatan, 94\% kasus meninggal covid-19 belum vaksinasi (Kemenkes, 2021). Vaksinasi sangat penting untuk membentuk kekebalan kelompok. Upaya ini tidak mudah karena sebagian masyarakat tidak mau divaksin dengan berbagai alasan. Di sisi lain, pemerintah harus memastikan ketersediaan vaksin untuk semua lapisan masyarakat, khususnya warga sekolah. Meski tidak menjadi syarat utama untuk PTM terbatas, vaksin warga sekolah akan meminimalisir penularan virus. Pemerintah juga harus menyiapkan tenaga kesehatan yang cukup, dan memerhatikan gaji dan tunjangan mereka.

\section{Dampak Penutupan Sekolah}

Dampak penutupan sekolah membuat siswa menjadi tidak memperoleh pendidikan secara maksimal, adapun efek yang sangat signifikan yang dirasakan peneliti diantaanya; 1) Penutupan sekolah yang terlalu lama memiliki konsekuensi yang signifikan, terutama bagi anak-anak dari kelompok paling marjinal, termasuk yang berasal dari kelompok ekonomi kurang mampu, yang tinggal di perdesaan dan daerah terpencil, dan anak dengan disabilitas; 2) Penutupan sekolah dan isolasi sosial, serta ketidakpastian ekonomi yang menyertai, memiliki dampak signifikan terhadap kesejahteraan psikososial dan kesehatan mental anak, bahkan Faiz et al (2021) menambahkan Kondisi pembelajaran dari rumah atau online membuat siswa dan orang tua tertekan. Hal ini bisa meningkatkan resiko kekerasan antara orang tua dan anaknya/ siswa; 3) Banyak anak dan keluarga yang sulit melakukan pembelajaran jarak jauh (PJJ) karena ketiadaan sarana penunjan (Tidak memiliki gawai, tidak terkoneksi dengan internet, tidak memiliki listrik); 4) Kehilangan hak: belajar, berteman, rasa aman, Kesehatan, kesejahteraan; 5) Anak di luar sekolah juga lebih berisiko menjadi korban eksploitasi ataupun kekerasan fisik, emosional, dan seksual; 5) Jika kelanjutan pembelajaran tatap muka tidak diprioritaskan, terdapat risiko bahwa kemajuan yang telah dicapai di bidang pendidikan dalam beberapa tahun terakhir akan hilang (learning loss).

Kebijakan pembelajaran pada masa pandemi telah disesuaikan beberapa kali dengan pertimbangan keselamatan, kesehatan, dan evaluasi capaian belajar. Penyesuaian SKB 4 Menteri sejak 2020:

1. Tanggal 24 Maret - 15 Juli 2020 yaitu SE Mendikbud No. 4 Tahun 2020, tentang; Belajar dari rumah, Ujian Nasional ditiadakan, PPDB Online dan dilarang kerumuman. 
5022 Implementasi Pembelajaran : Peluang dan Tantangan Pembelajaran Tatap Muka bagi Siswa Sekolah Dasar di Muara Komam - Adiyono

DOI: https://doi.org/10.31004/edukatif.v3i6.1535

2. Tanggal 15 Juli - 7 Agustus 2020 yaitu Implementasi SKB 4 Menteri, tentang; Dapat membuka PTM dengan syarat, Belajar dari rumah (kode kuning), Belajar dari rumah (kode oren), dan Belajar dari rumah (kode merah).

3. Bulan Agustus - Desember 2020 yaitu penyesuaian SKB 4 Menteri, tentang; Dapat membuka PTM dengan syarat dan Belajar dari rumah.

4. Bulan Januari - Maret 2021 yaitu penyesuaian SKB 4 Menteri, Mulai Januari 2021, apabila Pemda sudah memberikan izin dan satuan pendidikan memenuhi semua syarat berjenjang, maka PTM diperbolehkan, namun tidak wajib.

5. Bulan April - Sekarang yaitu penyesuaian SKB 4 Menteri,mulai April 2021, apabila seluruh PTK pada satuan pendidikan telah divaksin, satuan pendidikan wajib memberi opsi PTM Terbatas (dengan prokes) dan PJJ. Sesuai kebijakan pemerintah pusat, yang diberlakukan saat ini adalah pembelajaran berdasarkan situasi Covid-19 (PPKM Level 1,2 dan 3).

\section{KESIMPULAN}

Pembelajaran luring terbatas bermakna bahwa pembelajaran dilakukan secara bauran, hibdrid, atau blended. Pembelajaran dilakukan di sekolah dan di rumah. Artinya, kehadiran internet dan kepemilikan laptop masih sangat perlu. Kuota internet tetap diperlukan. Guru menyiapkan kurikulum pembelajaran yang dipakai secara luring dan daring. Guru harus terus belajar dan meningkatkan literasi digital agar siswa senang dan aktif dalam belajar. Tidak kalah penting adalah peran orang tua dalam mendampingi dan memotivasi belajar anak di rumah. Orang tua juga harus siap memenuhi kebutuhan belajar anak, seperti laptop, kuota internet, dan bahan-bahan tugas sekolah, yang pengadaannya kadang mendadak atau saat itu juga.

\section{DAFTAR PUSTAKA}

Andrianto Pangondian, R., Insap Santosa, P., \& Nugroho, E. (2019). Faktor - Faktor Yang Mempengaruhi Kesuksesan Pembelajaran Daring Dalam Revolusi Industri 4.0. Sainteks, 56-60.

Faiz, A. (2019). Program Pembiasaan Berbasis Pendidikan Karakter Di Sekolah. Pgsd Universitas Muhammadiyah Cirebon, 5(20). Https://Doi.Org/Htps://Doi.Org/10.32534/Jps.V5i2.741

Faiz, A., Hakam, K. A., Nurihsan, J., \& Komalasari, K. (2021). Development Of Moral Dilemma Model In Elementary School. 1st International Conference In Education, Science And Technology, 17-22.

Faiz, A., \& Kurniawaty, I. (2020). Konsep Merdeka Belajar Pendidikan Indonesia Dalam Perspektif Filsafat Progresivisme. Konstruktivisme: Jurnal Pendidikan Dan Pembelajaran. Https://Doi.Org/Https://Doi.Org/10.35457/Konstruk.V12i2.973

Faiz, A., \& Soleh, B. (2021). Implementasi Pendidikan Karakter Berbasis Kearifan Lokal. Jinop (Jurnal Inovasi Pembelajaran), 7(1), 68-77. Https://Doi.Org/10.22219/Jinop.V7i1.14250

Faiz, A., Soleh, B., Kurniawaty, I., \& Purwati. (2021). Tinjauan Analisis Kritis Terhadap Faktor Penghambat Pendidikan Karakter Di Indonesia. Jurnal Basicedu, Volume 5(4), 1766-1777. Https://Doi.Org/Https://Doi.Org/10.31004/Basicedu.V5i4.1014

Hanina, P., Faiz, A., \& Yuningsih, D. (2021). Upaya Guru Dalam Mengatasi Kejenuhan Belajar Peserta Didik Di Masa Pandemi. Basicedu, 5(5), 3791-3798. Https://Doi.Org/10.31004/Basicedu.V5i5.1402

Irlana, A., Retnasih, E., \& Faiz, A. (2021). Kolaborasi Manajemen Sekolah Dalam Meningkatkan Kualitas Pembelajaran Di Uptd Sdn 6 Margadadi. 246-253.

Jamilah, J. (2020). (2020). Guru Profesional Di Era New Normal: Review Peluang Dan Tantangan Dalam Pembelajaran Daring. Premiere Educandum : Jurnal Pendidikan Dasar Dan Pembelajaran, 10(2). 
5023 Implementasi Pembelajaran : Peluang dan Tantangan Pembelajaran Tatap Muka bagi Siswa Sekolah Dasar di Muara Komam - Adiyono

DOI: https://doi.org/10.31004/edukatif.v3i6.1535

Kemendikbud. (2021). Kesiapan Proses Belajar Mengajar Satuan Pendidikan Di Masa Pandemi Covid-19. Kemendikbud.Go.Id.

Kemendikbudristek. (2021). Surat Keputusan Kemendikbudristek Dan Instruksi Mendagri.

Kemenkes. (2021). Surat Edaran 4 Menteri No. Hk 02.01/2021 Dan Surat Edaran Dirjen P2p Kemenkes No. Hk.02.02./Ii/1444/2021 Dan Beberapa Sr Lainnya). Dirjen P2p Kemenkes.

Kuntari Erimurti. (2016). Pemanfaatan Teknologi Informasi Dan Komunikasi Untuk Meningkatkan Kualitas Pembelajaran Matematika. In Direktorat Jenderal Guru Dan Tenaga Kependidikan Kementerian Pendidikan Dan Kebudayaan. Pusat Pengembangan Dan Pemberdayaan Pendidik Dan Tenaga Kependidikan Seni Dan Budaya, Direktorat Jenderal Guru Dan Tenaga Kependidikan.

Kurniati, E., Nur Alfaeni, D. K., \& Andriani, F. (2020). Analisis Peran Orang Tua Dalam Mendampingi Anak Di Masa Pandemi Covid-19. Jurnal Obsesi: Jurnal Pendidikan Anak Usia Dini, 5(1), 241. Https://Doi.Org/Https://Doi.Org/10.31004/Obsesi.V5i1.541

Mega Persada, N., Eko Pramono, S. (2017). Pelibatan Orang Tua Pada Pendidikan Anak Di Sd Sains Islam Al Farabi Sumber Cirebon. Http://Journal.Unnes.Ac.Id/Sju/Index.Php/Eduman, 6(2), 100-108.

Nizam, \& Aris, J. (2009). Panduan Pembelajaran Daring Bagi Mahasiswa Dengan Disabilitas Fisik.

Peimani, N., \& Kamalipour, H. (2021). Online Education And The Covid-19 Outbreak: A Case Study Of Online Teaching During Lockdown. Education Sciences, 11(2), 1-16. Https://Doi.Org/Doi:10.3390/Educsci11020072

Pradina, Q., Faiz, A., \& Yuningsih, D. (2021). Peran Guru Dalam Membentuk Karakter Disiplin ( Studi Pada Siswa Di Mi Nihayatul Amal Gunungsari Cirebon ). Jurnal Ilmu Pendidikan, 3(6), 4118-4125.

Sukur, Moch Halim. (2020). Penanganan Pelayanan Kesehatan Di Masa Pandemi Covid-19 Dalam Perspektif Hukum Kesehatan. Journal Inicio Legis, 1(1), 1-17.

Suni Astini, N. K. (2020). Tantangan Dan Peluang Pemanfaatan Teknologi Informasi Dalam Pembelajaran Online Masa Covid-19. Cetta: Jurnal Ilmu Pendidikan, 3(2), 241-255. Https://Doi.Org/Doi.Org/10.37329/Cetta.V3i2.452. 